\title{
Sistematies verwronge kommunikasie in Lukas 14:1-6: \\ Die dialekties-kritiese teorie van \\ Jürgen Habermas krities bespreek
}

\author{
G J Volschenk \& A G van Aarde \\ Universiteit van Pretoria
}

\begin{abstract}
Systematically distorted communication in Luke 14:1-6: A critical assessment of the dialectical-critical theory of Jürgen Habermas In this article the epistemology and essence of the practical interest of Jürgen Habermas's dialectical-critical theory is discussed, focusing on his concept of systematically distorted communication. The article aims at describing the theory of communicative competence or universal pragmatics by means of an exegetical study of Luke 14:1-6. The appropriation of Habermas's theory on Luke 14:1-6 is assessed from the perspective of some results of the recent social-scientific studies of the New Testament.
\end{abstract}

\section{INLEIDING}

Habermas word met die kritiese teorie van die Frankfurtse Skool geassosieer. Dit is egter belangrik om te onthou dat hy die kritiese teorie langs ander weë en probleemstellings ontwikkel het as die ouer lede van die skool. Vir Habermas gaan dit om die presisering van die sogenoemde emansipatoriese belang: die wyse waarop kennis oor die samelewing gevorm word, word openbaar gemaak sodat mense hulle eie sosiale omstandighede kan verstaan en op grond hiervan die omstandighede self kan begin verander. Habermas is veral geinteresseerd in die wyse waarop sy bevrydingsteorie pragmaties deur kommunikasie onderbou word. Hiermee saam is sy fokus gerig op die voorwaardes van 'n toereikende, maar kritiese, interpreterende sosiale wetenskap. Die tema van die verifikasie van sosiologiese kennis word derhalwe deur hom herformuleer (kyk Romm 1987:179). Habermas (1985) het teen 1981 sy subjekgesentreerde kenteoretiese paradigma verruil vir 'n kommunikasieteoretiese paradigma. Hierdie studie konsentreer op Habermas se werke voor hierdie paradigmaverskuiwing by hom plaasgevind het (kyk Habermas 1982, 1983, 1985, 1986).

* Ingedien en aanvaar as deel van dic vereistes vir die MDiv-graad, Fakulteit Teologic (Afd A), Universiteit van Pretoria, onder leiding van prof dr A G van Aarde. 
Die program van ondersoek kan soos volg uiteengesit word: In afdeling 2 word die epistemologie grondliggend aan (epistemologiese transformasie) en die aard van die pragmatiese belang (sosiale transformasie) van die dialekties-kritiese teorie van Habermas kortliks bespreek.

Volgens hom word alle kennis beïnvloed deur belange - wat Habermas die emansipatories-kognitiewe belang noem. Hermeneutiese refleksie behoort krities te funksioneer teenoor enige tradisie wat nie gevorm is in die konteks van 'n sodanige emansipatoriese belang nie. Die kritiese teorie ondersoek die moontlikheid dat magsverhoudings heimlik in gegewe simboliese strukture van taal en handelinge opgeneem is. Die eietydse tradisionele hermeneutiek word derhalwe deur Habermas vervang met 'n 'diepte-hermeneutiek' wat afgestem is op die ontdekking van verwringings in kommunikasie soos wat hulle opkom uit die magsverhoudings in die samelewing. In terme van hierdie 'diepte-hermeneutiek' word ruimte geskep vir kritiek op die manipulerende kulturele tradisie van die dag en vir 'n alternatiewe toekoms (Romm 1987:189). Habermas wil 'n tipe sosiale wetenskap vestig wat spesifiek afgestem is op die emansipatories-kognitiewe belang ter wille van die mens se aktiewe bemoeienis met die geskiedenis (Romm 1987:180).

In afdeling 3 word die begrip 'sistematies verwronge kommunikasie' kortliks bespreek. Habermas gaan van die veronderstelling uit dat 'tradisie' realisties gesien, geëvalueer moet word as ' $n$ ideologiese draer van oorheersing en onderdrukking. Hy het dus 'n probleem met die verskynsel dat die 'tradisie' 'n legitimiteitsfunksie het. 'Tradisie' is volgens hom onderhewig aan verwringing van 'n sosio-ekonomiese aard (vgl Maddox 1985:524). Volgens Maddox (1985:528) het hierdie kritiese refleksie sover gegaan as om alle klassieke uitdrukkings van Christelike tradisie as fundamenteel verwronge kommunikasie te bevraagteken. Hierdie verwringing word toegeskryf aan sosio-ekonomiese, rassistiese en seksistiese belange. Daar is teoloë wat hiervan oortuig geraak het en nou op grond van 'n beginsel van bevryding die Christelike geloof vry van verwringing wil rekonstrueer. Die vraag is: Is alle tradisie verwring? Is alle verwringing toe te skryf aan sosioekonomiese, rassistiese en seksistiese belange? Is nie-verwronge of belangelose tradisie enigsins moontlik?

Die ideale gespreksituasie veronderstel dat die motiverende basis van enige aksie taalkundig georganiseer word - aksies waarin die werklike motiverings van die akteurs dieselfde is as die taalkundig verstaanbare intensies van die sprekers (Habermas [1970] 1981b:233). Die ironie is dat in die werklikheid die sosiale aksie nie beheer word deur die motiewe wat saamval met die intensie van die akteurspeker nie, maar deur verskuilde motiewe. Hoe meer daar verskuilde motiewe is wat nie in die publieke kommunikasie oorgedra word nie, hoe groter is die afwyking van die model van 'n 'suiwer' kommunikatiewe aksie (Habermas [1970] 1981b:233). 
Habermas ([1970] 1981b:234) maak twee empiriese aannames:

- dat hierdie afwykings in proporsie toeneem tot die mate van onderdrukking wat die institusionele sisteem in 'n gegewe gemeenskap kenmerk; en

* dat die mate van onderdrukking afhang van die ontwikkelingsfase van die produktiewe kragte en van die organisering van die gesag, dit wil sê die institusionalisering van politieke en ekonomiese mag.

In afdeling 4 word Habermas se teorie van kommunikatiewe kompetensie (universele pragmatiek) uiteengesit. Habermas poog om 'n teorie van kommunikatiewe aksie of kompetensie voor te stel wat normatiewe sosiale kritiek moontlik maak. Dit behels die uitwerk van 'n stel rasionele norme of standaarde om kritiese oordele te vel en om sosiale aksies te rig. Hy beweer dat ons die gewensde norme kan vasstel deur die kommunikatiewe aksie te analiseer. Sodoende word die kommunikatiewe aksie se universele en onafwendbare voorwaardes gerekonstrueer. Die aanname is dat kommunikasie veronderstel 'n ideale gespreksituasie waarin die gespreksgenote self vrylik vir die diskussie verantwoordelik is en waarin niemand uitgesluit is van die diskussie deur mag nie. Beginsels wat as norme van kritiek gebruik kan word, word afgelei vanuit die ideale gespreksituasie soos voorgestel deur die werking van kommunikatiewe kompetensie. Hy noem sy kritiese filosofie 'n 'universele pragmatiek' of 'n teorie van 'kommunikatiewe kompetensie of aksie'. Sy kritiese teorie wil die verwringings binne 'n tradisie ontmasker met die oog op die skep van 'n vry samelewing ('free society'; vgl Habermas [1970] 1981a:203, 204).

Om deel te neem aan 'n normale diskoers moet sprekers die volgende tot hulle beskikking hê: saam met hulle linguistiese kompetensie, moet hulle ook basiese kwalifikasies besit om gesprek en simboliese interaksie (rol-gedrag) moontlik te makk. Dit word kommunikatiewe kompetensie genoem. Die skep van 'n situasie van potensiële kommunikasie is op sigself deel van die algemene kompetensie van die ideale spreker. Met ander woorde, die situasie waarin die ideale gesprek (dit wil sê, die toepassing van linguistiese kompetensie) in beginsel moontlik word, hang af van die struktuur van intersubjektiwiteit (wat ook linguisties van aard is). Dus, kommunikatiewe kompetensie beteken die bemeestering van 'n ideale gespreksituasie (Habermas [1970] 1981b:227).

In afdeling 5 word die sistematies verwronge kommunikasie in Lukas 14:1-6, indien enige, aangetoon. En in afdeling 6 word die toepassing van Habermas se teorie op Lukas 14:1-6 geëvalueer vanuit die perspektief van sekere resultate van resente sosiaal-wetenskaplike studies van die Nuwe-Testament. 
2. DIE EPISTEMOLOGIESE TRANSFORMASIE EN PRAGMATIESE BELANG (SOSIALE TRANSFORMASIE) VAN DIE DIALEKTIES-KRTTIESE TEORIE

Die dialektiek in die dialekties-kritiese teorie bestaan uit die aantoon van die singewing van waardes deur middel van die beoefening van wetenskap. Dit word gerugsteun deur rekenskap te gee van die wese van dit waarmee die sosiale wetenskappe hulle besig hou, naamlik die samelewing (Snyman 1987:156). Hierdie dialekties-kritiese teorie kan omskryf word as die emansipatories-kognitiewe belang. Habermas (in Romm 1987:190) is van mening dat 'n 'dialektiese' sosiologie wat 'n verbintenis tot waardebetrokkenheid het, daartoe in staat is om die ware aard van die sosiale werklikheid te waardeer as 'n werklikheid wat deur die mens beheer word. En verder stel hy dat 'n 'dialektiese' sosiologie wat deur die emansipatoriese belang gelei word, in staat is om die feit te begryp dat die sosiale werklikheid radikaal verander kan word deur bewuste menslike optrede. Die kognitiewe is so met die emansipatoriese komponent in hierdie belang ineengevleg dat dit net vir analitiese doeleindes onderskei kan word. Dit moet dus nie gesien word as twee opeenvolgende fases van die teorie nie.

Een van die belangrikste kriteria vir wat as 'waar' in sosiaal-wetenskaplike kennis geld, het in die 'dialektiese' sosiologie te doen met wat as konsensusteorie bekend staan. Dit kom daarop neer dat die relasie teorie en feit as van wesenlike betekenis vir wetenskaplike waarheid geag word. Die konsensus staan bekend as die argumentatief-geldige konsensus. Alleen deur argumentvoering kan 'n beginsel verander word. Hierdie konsep staan teenoor die korrespondensieteorie van waarheid, omdat dit die ooreenkoms tussen teorie en feit as vertrekpunt neem (Gorski 1990:287). 'n Belangrike konsekwensie van die konsensusteorie van waarheid is dat dit ruimte skep vir verskillende soorte kennis. Gevolglik onderskei Habermas (in Romm 1987:180; kyk ook McCarthy 1978:60-90) tussen die tegniese belang van die empiries-analitiese wetenskappe, die praktiese belang van die kulturele of hermeneutiese wetenskap en die emansipatoriese belang van die kritiese teorie.

Die emansipatories-kognitiewe belang is vir Habermas die belang wat daarop gerig is om menslike outonomie en verantwoordelikheid in die historiese proses te verwesenlik. Hierdie kennis het die voordeel dat dit in staat is om die belang aan die hand waarvan die mens gelei word, te erken. Dit maak die verhouding tussen kennis en belange openbaar, terwyl dit daarop aandring dat die waarheid van stellings gekoppel is aan die intensie om die goeie en ware lewe te bevorder (die sogenoemde 'konsensusteorie'). Kennis wat die emansipatoriese belang in sigself opneem, neem die verband tussen feite en waardes as die vertrekpunt. Daarmee 
word erken dat teoretiese stellings nie waardevrye beskrywings van die werklikheid is nie, maar eerder waardegelaaide voorskrifte van wat gedoen behoort te word om 'n beter toekoms vir die samelewing te skep (vgl Romm 1987:190).

Volgens Habermas (in Romm 1987:180) is kennis wat voortgebring is in terme van die emansipatoriese belang, waardegelaai deurdat dit die doelwit (waarde) van 'n samelewing vry van verwronge kommunikasie bevorder en aanmoedig. 'n Sodanige kennisbegrip het 'n duidelike voorskriftelike inhoud: die norm is 'n samelewing van onbelemmerde kommunikasie tussen die deelnemers. Hierdie kennis manifesteer as 'waar' wanneer die onbelemmerde diskoers wat in die teorie geponeer word, 'n werklikheid word.

'n 'Dialektiese' sosiologie wat 'n erkende belang by 'emansipasie' het, is ook in staat om aan te toon dat sowel die empiries-analitiese as die (oppervlakte-) hermeneutiese sosiologie inmeng met die potensiaal van die mensheid om beheer te verkry oor die rigting van die geskiedenis. (Oppervlakte-hermeneutiek moet gesien word as die teendeel van diepte-hermeneutiek.) Empiries-analitiese kennis, byvoorbeeld, belemmer die vermoë van die mens om iets aan die gang van die geskiedenis te doen omdat dit die reëlmaat wat in die samelewing 'ontdek' word, verkeerdelik as onveranderlik bestempel. En die oppervlakte-hermeneutiese sosiologie belemmer die selfvormende proses van die mensdom omdat dit toelaat dat die gegewe betekenisse wat in die kulturele tradisies van 'n samelewing beliggaam word, tot aanvaarde en gefikseerde groothede stol (kyk Maddox 1985:528; Romm 1987:190). Habermas se argument kom daarop neer dat 'n sosiologie wat die gesigspunt van die emansipatoriese belang bewustelik aanvaar, nie die sosiale aard van die werklikheid verwring nie, maar inderdaad meebring dat die ware aard van hierdie werklikheid verstaan kan word.

Volgens Romm (1987:191) beweer Habermas dat sy kritiese teorie sy 'waarheid' sal bevestig deur 'n proses van selfrefleksie te begin wat tot die emansipasie van die lede van die samelewing sal lei. Dit dien ook as die verifikasiekriterium. Habermas regverdig die gebruik van hierdie verifikasiekriterium deur daarop aanspraak te maak dat dit die verifikasiemetode is wat in die psigo-analise gebruik word. In die psigo-analise word die waarheid van die psigo-analis se interpretasie van die pasiënt se neurose 'bewys' as die pasiënt hierdie interpretasie begin aanvaar. Daardeur word die pasiënt in staat gestel om te reflekteer oor die beperkinge wat sy gedrag voorheen beheer het.

Habermas redeneer dat die sosiologiese teorie wat die 'neurose' van die samelewing 'diagnoseer', op dieselfde wyse as korrek gedui kan word. Verifikasie en falsifikasie berus op die feit dat die individue in 'n samelewing die krities-teoretiese interpretasie van hulle nood aanvaar en dit as 'n basis vir selfrefleksie gebruik. 
Hierdie selfrefleksie is ' $\mathrm{n}$ proses waarin individue bewus word van hulle krag teen 'feitelike' of 'tradisionele' magte in die samelewing. Die nadenke of refleksie oor hierdie kragte lei tot die ontkragting van die mag wat dit oor die slagoffer het. Laasgenoemde sien nou in dat die voortdurende instandhouding van hierdie kragte op die onnadenkende aanvaarding daarvan berus. Habermas beweer dat sodra individue in 'n samelewing insig verkry het in die veranderende aard van die sosiale wette of gestolde tradisies wat hulle optredes beheer, die mag van hierdie wette en tradisies verbreek sal word en emansipasie dan kan plaasvind (vgl Romm 1987:192).

Volgens Habermas is die diskoers wat in staat sal wees om oor die waarheid van die teorie te beslis, 'n onmoontlikheid onder die gegewe omstandighede waar magsverhoudings en allerhande vorme van oorheersing steeds heimlik in ons simboliese strukture geïnkorporeer word. Voordat 'n dialekties-kritiese teorie sigself as 'geldig' kan toon, moet dit oor die vermoë beskik om daardie aspek van taal uit die weg te ruim wat die taal ' $n$ medium laat word vir manipulerende magsverhoudings in die samelewing.

Selfrefleksie moet geskep word omdat rasionaliteit in die samelewing nie as rasioneel ervaar word nie: die rasionaliteit van die produksieprosesse mag wel vir die rede begrypbaar wees, maar dit is irrasioneel in die vernietiging van mense se vryheid en die lyding wat dit meebring. Die toename in tegniese middele om die natuur te beheers, mag weliswaar 'n toename in welvaart beteken het, maar dit het geskied ten koste van die kreatiwiteit van die mens in sy arbeidsituasie, in sy denke en in sy gevoel. Dit kom neer op die verdingliking van die mens. Die rasionaliteit van die samelewing is dus paradoksaal irrasioneel van aard: dit maak tegniese vooruitgang moontlik, maar onderdruk die mens. Die verandering van die ervaringsbegrip is om die ervaring van die versluierde probleme van die samelewing moontlik te maak. Die kritiese teorie is geïnteresseerd in die redeliker organisasie van die samelewing op grond van die ervaring van die nood van die huidige toestand. Die ervarings van spannings in die huidige samelewing klop nie met die insig van 'n samelewing nie, en ook nie met die insig wat die samelewing van sigself uitstraal nie. Hierteenoor openbaar die kritiese teorie 'n begrip van en insig in die geëksploiteerde mens; ' $n$ begrip wat met sigself in stryd is solank as wat identiteit tussen begrip en saak (in hierdie geval: die geëksploiteerde mens) nie herstel is nie. Die kritiese element van die kritiese teorie se siening van die verhouding tussen (algemene) begrip en saak, is dat die saak nie sonder meer 'n eksemplaar en dus 'n bevestiging van die begrip is nie. Die neo-Marxis, Theodor Adorno, noem dit by geleentheid immanente kritiek wat nie net daarom gaan om vas te stel op watter punte die saak met homself klop nie, maar wat eerder 'n konfrontasie van begrip met saak is (kyk Snyman 1987:170). 
'n Kritiese teorie kom derhalwe op gang as gevolg van 'n negatiewe ervaring. Die inhoud van daardie ervaring is materialisties, naamlik pyn. Die feit dat daar pyn en lyding in die wêreld voorkom, beteken dat die samelewing nog nie is wat dit behoort te wees nie. Alle samelewings kan hiertoe 'gereduseer' word, naamlik tot 'n strategie om fisiese nood te bekamp. Die voorkoms van lyding verhinder vooruitgang. Waar daar dus sprake is van pyn en lyding, is daar sprake van 'n spanning tussen die saak self en wat in begrippe oor die samelewing gegee word. En om die spannings te verklaar, moet verdere begrippe ingespan word. Daarvoor word 'n teorie ontwerp om die saak te dui wat sigself kenbaar gemaak het in 'n negatiewe ervaring van pyn. Sodoende word die kritiese teorie 'n kritiese ontsyfering van sosiale fenomene.

Die neo-Marxiste het in hulle samelewingsbeskouing een punt besonderlik met Karl Marx in gemeen, en dit is om die samelewing te verander. Die dialektieskritiese teorie het ook die 'impuls' om die werklikheid te verander. Kritiese teorie beoog derhalwe om die onopgeloste spannings in die bestaande sosiale werklikheid te identifiseer en daardeur ' $n$ bewussynsverandering teweeg te bring. Dit wil sigself egter weerhou van bloudrukke van die toekoms sodat dit gevrywaar is van die kwaad wat in die bestaande sosiale opset gediagnoseer word, naamlik die mag van mense oor mense en dinge. Maar deur ' $n$ bewuswordingsproses aan die gang te sit, hoop en vertrou die neo-Marxiste om 'n verandering van onder en van binne, beslis nie van bo nie, op tou te sit. Dit gaan daarom dat die 'verbindingssamehang' tot 'selfbewussyn' gebring moet word. Sodra dit gebeur, sal die houvas op die denke van die mens verbreek wees. As die verdingliking van byvoorbeeld die proletariaat bewus en selfbewus gemaak kan word (deur middel van filosofiese analise), kan daar ook meer doelbewus gewerk word aan die geskiedenis van die verandering van die samelewing. Dan is die verandering van die samelewing nie meer 'n outomatiese, kousale historiese prosedure nie, maar is dit die gevolg van die insette van 'n selfbewuste mens. Die geskiedenis en maatskaplike proses voltrek dan nie meer bo die koppe van mense heen nie, maar deur die bewuste deelname van mense (vgl Habermas 1977:136-142; Snyman 1987:166; Gorski 1990:302).

Die kritiese teorie word gelei deur ' $n$ analise van die historiese verloop wat 'n belang het by die toekoms. Die selfbewuste mens bly derhalwe betrokke by die historiese proses. Die siening dat daar patrone in die geskiedenis is wat aan die geskiedenis 'n voorspelbare reëlmatigheid verleen, beteken 'n onkritiese aanvaarding van die selfstandigheid van die feite ten koste van menslike betrokkenheid by en in daardie feite. Die kritiese teorie gaan ook nie van die aanname uit dat in die wetenskaplike proses die subjek (mens) en die objek (in die geval: samelewingsprosesse) losstaande entiteite is nie. Wat in die sosiologie bestudeer word, is nie iets los van die wetenskaplike wat die ondersoek loods nie (vgl Snyman 1987:167). 


\section{SISTEMATIES VERWRONGE KOMMUNIKASIE}

\subsection{Wat is sistematies verwronge kommunikasie?}

In sistematies verwronge kommunikasie word onverstaanbaarheid gesien as die resultaat van 'n foutiewe organisering van die gesprek self. Dit kom byvoorbeeld voor by patologiese gespreksteurings soos by psigote. Verder kry ons dit ook by pseudo-kommunikasie waar deelnemers geen kommunikasiesteurings erken nie. Dit is ' $n$ sisteem van wedersydse misverstand wat, as gevolg van valse aannames van konsensus, nie erken word nie. Die enigste manier waarop hierdie misverstand uit die weg geruim kan word, is deur wedersydse kommunikasie deur die deelnemers aan die gesprek (Habermas [1970] 1981a:209). Psigo-analise word daarom deur Habermas ([1970] 1981a:210) as 'n soort taalanalise beskou.

Kommunikatiewe aksie kan onverwring voortgaan solank die deelnemers veronderstel dat die geldigheidsaansprake wat hulle wedersyds opper, vir beide geregverdig is. Om in ' $n$ proses deel te neem wat tot verstaan sal lei, geld die volgende geldigheidsaansprake ('validity claims'):

* die spreker moet verstaanbare (comprehensible/verständliche) uitdrukkings kies, sodat spreker en hoorder mekaar kan verstaan;

* die spreker moet die intensie hề om 'n ware (true/wahr) stelling te kommunikeer, sodat die hoorder die spreker se kennis kan deel;

- die spreker moet sy/haar intensies betroubaar (truthfully/wahrhaftig) uitdruk, sodat die hoorder die uitdrukking van die spreker kan glo (hom/haar kan vertrou); en

* die spreker moet 'n uitdrukking kies wat korrek (right/richtig) is, sodat die hoorder die uitdrukking kan aanvaar en die spreker en hoorder met mekaar kan ooreenstem in terme van 'n erkende, normatiewe verwysingsraamwerk (Habermas 1979:3; McCarthy 1978:280; McCarthy 1979:xx).

'n Volledige eenstemmigheid (wat al vier hierdie komponente insluit) dui ideale kommunikasie aan. Die tipiese situasie is egter die grys gebied tussen twee pole. Aan die een kant is dit onbegrip en misverstand, doelbewuste en gedwonge onbetroubaarheid, verborge en openlike disharmonie. Aan die ander kant is dit die reeds bestaande of preëksistente of bereikte konsensus. Om egter te verstaan is samevattend gesien die proses om 'n ooreenkoms te bereik op grond van die vooronderstelde basis van geldigheidsaansprake wat wedersyds erken word (Habermas 1979:3). 
3.2 Drie kriteria om spesifieke onverstaanbare aksies en uitdrukkings te definieer

\subsubsection{Op die vlak van taal}

Verwronge kommunikasie kom voor wanneer taalreëls gebruik word wat afwyk van die erkende sisteem van linguistiese reëls. Spesifieke semantiese inhoude of volledige semantiese velde of selfs sintaksis kan geaffekteer word.

\subsubsection{Op die handelingsvlak}

Verwronge taalgebruik manifesteer in die vorm van rigiede en gedwonge herhalings. Sulke stereotipe gedragspatrone is eie aan situasies waar sekere stimuli emosioneel gelaaide reaksies veroorsaak. Hierdie onbuigbaarheid is simptomaties van die feit dat semantiese inhoude hulle spesifieke linguistiese afhanklikheid van die onderskeie situasionele kontekste verloor het.

3.2.3 Op die vlak van 'leë gebare of vergissings'

Wanneer die sisteem van verwronge kommunikasie in geheel gesien word, is die diskrepansie tussen die vlakke van kommunikasie opvallend: die gewone kongruensie tussen linguistiese simbole, handelinge en gepaardgaande gebare het verdwyn. Sulke kommunikasie is volgens die reëls van publieke kommunikasie onverstaanbaar en het as sulks privaat geword. Dit is selfs vir die outeur ontoeganklik. Daar is derhalwe 'n kommunikasie-obstruksie in die self, tussen die ek wat in staat is om te praat en deel te neem in 'n intersubjektief gevestigde taalspel en die 'innerlike vreemde terrein' (Freud) wat verteenwoordig word deur private of 'n primêre linguistiese simboliek (kyk Habermas [1970] 1981a:210).

\section{4. 'N MODEL VIR LINGUISTIESE KOMMUNIKASIE}

Universele pragmatiek of kommunikatiewe kompetensie behels die uitwerk van 'n stel rasionele norme (kyk afd 4.1) om kritiese oordele te vel en om sosiale aksies te rig. Universele pragmatiek identifiseer en rekonstrueer universele voorwaardes van moontlike verstaan (Habermas 1979:1). Beginsels wat as norme van kritiek gebruik kan word, word afgelei vanuit die ideale gespreksituasie (kyk afd 4.2) soos voorgestel deur die werking van kommunikatiewe kompetensie (kyk McCann 1981).

\subsection{Universele pragmatiek}

\subsection{1 'n Geldigheidsbasis vir gesprek}

\subsubsection{Geldigheidsaansprake}

Die doel om tot ' $n$ verstaan (Verständigung) te kom, is om 'n ooreenkoms (Einverständnis) te bereik. Dit eindig in die intersubjektiewe gemeenskaplikheid van wedersydse verstaan, gedeelde kennis, wedersydse vertroue en harmonie met mekaar. Ooreenkoms is gebaseer op die erkenning van die ooreenstemmende geldig- 
heidsaansprake van verstaanbaarheid, waarheid, betroubaarheid en korrektheid (kyk weer afd 3.1). Hieruit blyk dat verstaan 'n dubbelsinnige begrip is. Dit dui ten minste daarop dat twee subjekte 'n taalkundige uitdrukking op dieselfde wyse verstaan. Hoogstens het dit daarop betrekking dat daar eenstemmigheid tussen twee subjekte bestaan oor die korrektheid van 'n uitdrukking in relasie tot 'n gemeenskaplik erkende normatiewe verwysingsraamwerk (Habermas 1979:3).

\subsubsection{Konsensus}

Vervolgens sal ons nou die konsensus aantoon waraan taalhandelinge volgens Habermas moet voldoen. In kommunikatiewe aksie veronderstel die deelnemers dat hulle weet wat gemeenskaplike erkenning van wedersydse gemelde geldigheidsaansprake beteken. Konsensus bestaan uit die volgende:

* Spreker en hoorder weet implisiet dat elkeen die vier genoemde geldigheidsaansprake moet erken voordat daar enigsins sprake is van kommunikasie (of verstaan).

* Beide veronderstel dat hulle voldoen aan die vooronderstellings van kommunikasie wat daarop neerkom dat die geldigheidsaansprake geregverdig is.

* Enige sodanige geldigheidsaanspraak moet egter nog verwesenlik word, hoewel daar met betrekking tot die verstaanbaarheid van geuiterde sinne reeds 'ooreenkoms' bestaan. Konsensus ten opsigte van die waarheid, betroubaarheid en korrektheid van sinne, stellings en uitgedrukte intensies kom tot stand wanneer dit voldoen aan ooreenstemmende geskiktheidsvoorwaardes (kyk Habermas 1979:4).

\subsubsection{Drie aspekte van universele pragmatiek}

Verstaanbaarheid is die enigste universele geldigheidsaanspraak wat inherent aan taal is (Habermas 1979:28; McCarthy 1978:274). Teen die agtergrond van hierdie aanspraak onderskei Habermas tussen 'sin' (sentence) en 'uitdrukking' (utterance). 'n Sin wat uitgespreek word (met ander woorde, wat 'n 'uitdrukking' word) staan in relasie tot drie soorte realiteite: 'n eksterne realiteit, 'n interne realiteit en 'n normatiewe realiteit. Aan die hand van hierdie drie kategorieë identifiseer Habermas in die oppervlaktestruktuur van 'n sin eienskappe wat op drie pragmatiese funksies van 'n uitdrukking dui, te wete die representering van feite, die uitdrukking van intensie en die daarstelling van 'n legitieme interpersoonlike verhouding (Habermas 1979:28-33; McCarthy 1978:280).

Dit kan diagrammaties soos volg voorgestel word: 


\begin{tabular}{lll}
\hline Realiteitsgebied & $\begin{array}{l}\text { Universele pragma- } \\
\text { tiese funksie van } \\
\text { 'n uitdrukking }\end{array}$ & $\begin{array}{l}\text { Geldigheidsaanspraak } \\
\text { (Hoorder) }\end{array}$ \\
\hline Eksterne realiteit & $\begin{array}{l}\text { Representeer feite } \\
\text { (bestaande stand } \\
\text { van sake); Proporsio- } \\
\text { sionele sin }\end{array}$ & $\begin{array}{l}\text { Waarheid (deel } \\
\text { kennis) }\end{array}$ \\
\hline Interne realiteit & $\begin{array}{l}\text { Bekendmaking van } \\
\text { spreker se inten- } \\
\text { sies of subjek- } \\
\text { tiwiteit; lnten- } \\
\text { sionele nerkwoor- } \\
\text { de, modale vorme }\end{array}$ & $\begin{array}{l}\text { Betroubaar (hoorder } \\
\text { glo of vertrou } \\
\text { spreker) }\end{array}$ \\
\hline $\begin{array}{l}\text { Vestig 'n legitie- } \\
\text { me interpersoonli- } \\
\text { ke verhouding; } \\
\text { Performatiewe fra- } \\
\text { ses, illokusionê- } \\
\text { re indikators }\end{array}$ & $\begin{array}{l}\text { Korrektheid (hoorder } \\
\text { is eenstemmig ten op- } \\
\text { sigte van gedeelde } \\
\text { geldigheidsorien- } \\
\text { tasies }\end{array}$ \\
\hline
\end{tabular}

4.2 'n Teorie van kommunikatiewe kompetensie: Die bemeestering van 'n ideale gespreksituasie

Die derde pragmatiese funksie van 'n 'uitdrukking', naamlik die skep van interpersoonlike verhoudings, staan sentraal in Habermas se teorie van kommunikatiewe aksie (vgl Habermas [1970] 1981b:221; 1979:34). Daarom neem ons dié teorie van taalhandeling as ons vertrekpunt.

\subsubsection{Die standaardvorm van taalhandeling ('speech-act')}

\subsubsection{Die illokusionêre komponent}

Die hooftak van die taalhandelingteorie is om die performatiewe status van linguistiese uitdrukkings aan te dui. Die wyse waarop ' $n$ sin in 'n taalhandeling uitgedruk word, word die illokusionêre krag van die taalhandeling genoem. Dit kom daarop neer dat iets gedoen word deurdat iets gesê word (Habermas [1970] 
1981b:227; 1979:34). Werkwoorde soos belowe, aankondig, waarsku, rapporteer, begeer en bepaal, is voorbeelde van die uivoering van taalhandelinge (performance) en nie net verwysings na of beskrywings van handelinge nie. Die betekenis van 'n 'performatiewe uitdrukking' sluit in 'n referensie na:

- 'n handeling in 'n spesifieke en gepaste interaktiewe verhouding;

* die definisie van 'n (gepaste) situasie wat eksplisiet bepaal word deur die uitvoering van die gespreksituasie self; en

* die voorwaardelike inhoud van die afhanklike sinsnede.

Daar word in die taalhandelingteorie gevolglik onderskei tussen die vlakke 'iets sê' (die taal/lokusionêre vlak) en 'iets doen' (die handelings/illokusionêre vlak; Habermas [1970] 1981b:228; Botha 1991:64). Waar performatiewe uitdrukkings gebruik word, het die taalhandeling 'n linguistiese voorstelling van illokusionêre krag geword. In die algemeen gesien, is dit hierdie universele pragmatiese krag wat die betekenis van sekere geïdealiseerde kenmerke van 'n gespreksituasie verklaar. Sprekers sal dit moet kan bemeester as hulle kompetent vir enige deelname in situasies van potensiële gesprek wil wees. 'n Teorie van kommunikatiewe kompetensie kan dus volgens Habermas ontwerp word in terme van universele pragmatiek. Die performatiewe indikators word die diskoersoperateurs genoem, ofte wel, 'vormers' van die gespreksituasie. Alledaagse taalgebruik bevat performatiewe elemente wat taal in staat stel om gebruik te word as die taal van die taalhandeling. Die konsep 'taalhandeling' kan gevolglik as metataal getipeer word.

Die begrip 'illokusionêr' dui dus aan dat linguistiese uitdrukkings 'n pragmatiese karakter het en as ' $n$ taalhandeling gesien kan word. ' $n$ Taalhandeling is suksesvol as:

- 'n interpersoonlike verhouding tussen die spreker en hoorder tot stand kom - 'n verhouding wat deur die spreker bedoel is; en

* as die hoorder die inhoud van die spreker se uitdrukking verstaan en aanvaar soos dit deur die spreker bedoel is (Habermas 1979:35).

Die illokusionêre komponent bestaan met ander woorde uit 'n illokusionêre handeling wat uitgevoer word met die hulp van 'n performatiewe sin. Die sin word gevorm deur die indikatiewe teenwoordige tydsvorm (presens), met die eerstepersoon as die logiese subjek en die tweedepersoon as die logiese (direkte) objek: Ek.../werkwoord]...jou dat.../ = sin]. Byvoorbeeld: 'Ek belowe jou dat ek môre sal kom'. Die predikaat, gevorm met die hulp van 'n performatiewe uitdrukking, laat die partikel 'hierdeur' toe (Habermas 1979:34).

Aanwysende elemente verteenwoordig die ander klas van universele pragmatiek, byvoorbeeld persoonlike voornaamwoorde en uitdrukkings van tyd en plek. Die keuse tussen byvoorbeeld bepaalde en onbepaalde lidwoorde is nie kenmerke van die lidwoord self nie, maar van sekere pragmatiese verhoudings. 


\subsubsection{Die proposisionele komponent}

Die performatiewe komponent word voltooi deur 'n proposisionele komponent. Dit word gevorm deur 'n sin met proposisionele inhoud. So 'n sin bestaan uit:

* 'n naam of 'n verwysende uitdrukking waarmee die spreker 'n objek identifiseer waaroor hy/sy iets wil sê; en

* 'n predikaat of uitdrukking van karakterisering wat die spreker aan die objek wil gee of ontsê (Habermas 1979:36, 37).

'n Proposisionele sin het 'n verteenwoordigende funksie deurdat dit plaasvervangend van die bestaande stand van sake is. Dit representeer die eksterne realiteit.

Die analitiese eenheid kan in hierdie geval gedefinieer word as 'n proposisioneel gedifferensieerde en institusioneel ongebonde taalhandeling (Habermas 1979: 39). Met die uitdrukking 'proposisioneel gedifferensieerd' word bedoel dat die proposisionele komponent losgemaak is van die illokusionêre handeling, met die gevolg dat die proposisionele inhoud konstant bly te midde van die moontlike illokusionêre veranderlikhede. ('n Verbale uitdrukking is op grond van 'n spreker se situasie ryk aan alternatiewe.) Met die uitdrukking 'institusioneel ongebonde' word bedoel dat die uitdrukking onafhanklik is van die algemene konteks.

\subsubsection{Die dubbele struktuur van kommunikasie}

Die losmaking van illokusionêre en proposisionele komponente is 'n voorwaarde vir die onderskeid of differensiasie van die dubbele struktuur van kommunikasie. Dit is dus 'n voorwaarde vir die skeiding van die twee vlakke van kommunikasie waarop spreker en hoorder gelyktydig tot 'n verstaan kom as hulle hulle intensies aan mekaar wil kommunikeer. Die volgende twee vlakke word onderskei:

\subsubsection{Die vlak van intersubjektiwiteit}

Deur middel van illokusionêre handelinge bring die spreker en hoorder die verhoudings tot stand wat hulle in staat stel om tot 'n wedersydse verstaan te kom (Habermas [1970] 1981b:229; 1979:42; McCarthy 1978:282).

Die 'verbalisering' van pragmatiese kenmerke inherent aan die gespreksituasie verhef die illokusionêre krag of pragmatiese krag (wat alreeds in die struktuur van die gespreksituasie self gegenereer is) tot op die vlak van linguistiese kommunikasie. As gevolg van hulle illokusionêre krag is pragmatiese verhoudings van die begin af in die vorm van intersubjektiwiteit van wedersydse verstaan geïntegreer . Die linguistiese elemente (performatiewe en aanwysende) is die enigste faktore wat ons in staat stel om die struktuur van potensiële gesprek te genereer. Dit is hoofsaaklik hierdie dialoog-bepalende universele wat die vorm van intersubjektiwi- 
teit tussen vaardige sprekers (wat in staat is tot wedersydse verstaan) vestig. Kommunikatiewe kompetensie bestaan derhalwe uit die ideale spreker se bemeestering van die dialoog-bepalende universele, ongeag enige beperkings onder empiriese toestande. Die idealisering bestaan dus uit die feit dat ons ' $n$ besondere soort taalorganisering van kommunikasie en interaksie veronderstel.

\subsection{Die ideale gespreksituasie volgens die funksie van suiwer dialoog-} bepalende universele

* Die persoonlike voornaamwoorde (en hulle afleidings) wat 'n verwysingsisteem tussen potensiële sprekers vorm. Die bepaling van betekenis - die voorwaarde vir enige kommunikasie - is gebaseer op intersubjektiewe geldige reëls. Geldigheid is met ander woorde daarvan afhanklik dat ten minste twee sprekers intersubjektief die betekenis van 'n simbool verstaan op die basis van wedersydse erkenning. Alleen dan is dit vir 'n spreker in 'n gespreksituasie moontlik om vanuit sy/haar eie posisie en tegelykertyd vanuit dié van die ander persoon, betekenis te identifiseer en te verstaan. Slegs s6 deurvlegting van perspektiewe maak 'n intersubjektiewe geldige betekenistoekenning (en dus betekenisbepaling) moontlik (Habermas [1970] 1981b:230-232).

* Die aanwysende uitdrukkings van tyd en ruimte, asook lidwoorde en aanwysende voornaamwoorde wat 'n verwysingsisteem van moontlike denotasies vorm. Hulle verbind die vlakke van intersubjektiwiteit waaroor die subjekte met mekaar kommunikeer en die vlakke van objekte waaroor die subjekte opmerkings maak. Aanwysende uitdrukkings kan in twee skemas gekategoriseer word: tyd en ruimte, en substansie en oorsaak. Dit is uitdrukkings wat verwys na ervaring en na meetbare tyd en ruimte.

- Aanspreekvorme (vokatief), sosiale kontakvorme (groete), gespreksinleidings en -afsluitings, indirekte diskoers en vrae-en -antwoorde. Hulle is performatief omdat hulle gerig is op die gespreksituasie as sodanig. Hierdie vorme bepaal die struktuur van die potensiële gesprek en dit verklaar die pragmatiese betekenis van die gesprek self.

* Die basiese verskille wat nodig is vir enige gespreksituasie:

* Wese-en-voorkoms: uitdrukkings wat verwys na waarde-uitdrukkings volgens die prototipe van 'om te eis', 'aanspraak te makk' en 'om te betwis', vorm die dimensie van wese-en-voorkoms. Alle taalhandelinge impliseer 'n bedoelde konsensus oor dit wat werklik is, in onderskeid met dit wat bloot subjektief voorgee om te wees (die voorwaardelike intersubjektief erkende interpretasies en 'n private wêreld van persoonlike gevoelens en indrukke/belange). 
** Wese-en-essensie: uitdrukkings wat verwys na die selfvoorstelling van persone volgens die prototipe van 'om te openbaar' en 'te verberg', vorm die dimensie van wese-en-essensie. In alle kommunikasie gee subjekte in die uitvoering van die kommunikasie uitdrukking van hulle self wanneer hulle met mekaar praat oor sekere voorwaardelike onderwerpe. Dit veronderstel 'n verskil tussen kommunikasie oor objekte en metakommunikasie op die vlak van intersubjektiwiteit

** Wat is en wat behoort te wees: uitdrukkings wat verwys na die normatiewe status van reëls volgens die prototipe van 'om voor te skryf' en 'om te volg', vorm die dimensie van wat is en wat behoort te wees. Alle kommunikasie bestaan in ' $n$ konteks van handelinge en intensies. Die wedersydse erkenning van die subjekte wat met mekaar kommunikeer, sluit die sekerheid in dat hulle hulleself wedersyds teenoor mekaar se verwagtinge kan handhaaf deur op te tree volgens geldige norme. Dit veronderstel 'n onderskeid tussen geldige reëls wat doelbewus gevolg word en vaste waarneembare gebeure wat empiries vasgestel kan word.

\subsection{Simmetriese relasies vir die ideale gespreksituasie}

Hierdie relasies volg uit die analise van die struktuur wat voortgebring en beskryf is by wyse van suiwer dialoog-bepalende universele. Suiwer intersubjektiwiteit word bepaal deur 'n simmetriese verhouding tussen ek en jy (ons en julle), ek en hy (ons en hulle). 'n Onbeperkte wisselwerking van dialoogrolle vereis dat geen kant bevoordeel word in die vervulling van die rolle nie; suiwer intersubjektiwiteit bestaan slegs as daar ' $n$ suiwer simmetrie is in die verspreiding van selfhandhawing en dispuut, bekendmaking en verberging, voorskrywing en aanpassing tussen die deelnemers van kommunikasie. Solank hierdie simmetrie bestaan, sal kommunikasie nie gehinder word deur versteurings vanuit die kommunikasie se eie struktuur nie (vgl Habermas [1970] 1981b:232).

\subsection{Suiwer intersubjektiwiteit is ' $n$ idealisering}

'n Gespreksituasie wat deur intersubjektiwiteit bepaal word, kom neer op idealisering. Kommunikatiewe kompetensie beteken die bemeestering van die wyse van konstruksie wat noodsaaklik is vir die vestiging van 'n ideale gespreksituasie. Maak nie saak hoe die intersubjektiwiteit van wedersydse verstaan vervorm is nie, die ontwerp van 'n ideale gespreksituasie word noodwendig geïmplimenteer in die struktuur van die potensiële kommunikasie wat gerig is op die ideë van waarheid. Die ideale gespreksituasie kan gerealiseer word op grond van kommunikatiewe kompetensie en die empiriese struktuur van die sosiale sisteem waaraan ons behoort. Dit is moontlik om op grond van assimmetrie in die uitvoering van dia- 
loogreëls die vervorming van intersubjektiwiteit aan te toon wat deur die sosiale struktuur veroorsaak word. Die oneweredige verspreiding van dialoog-bepalende universele in standaard kommunikasie tussen individue en sosiale groepe toon die spesifieke vorm en vervorming van intersubjektiwiteit van wedersydse verstaan aan wat in die sosiale strukture ingebou is (vgl Habermas [1970] 1981b:232).

\subsubsection{Die vlak van proposisionele inhoud}

Soos ons reeds daarop gewys het, word die bestaande stand van sake deur proposisionele inhoude gekommunikeer (Habermas 1979:42). Inherente refleksiwiteit is 'n basiese kenmerk van taal. Dit is verbind met die sogenoemde dubbele struktuur van kommunikasie. Die standaard moontlikhede vir direkte en indirekte rede maak slegs ' $n$ selfrefleksie eksplisiet wat reeds in elke taalhandeling bestaan. Die deelnemers in dialoog kommunikeer op altwee vlakke gelyktydig.

\subsection{Suksesvolle kommunikasie}

Suksesvolle kommunikasie vind plaas as:

* institusioneel ongebonde taalhandelinge hulle illokusionêre krag te danke het aan 'n groep universele geldigheidsaansprake wat spreker en hoorder na vore bring en as geldig erken. 'n Voorwaarde vir verstaan is dat die geldigheidsaansprake op 'n aanvaarbare manier na vore moet kom (Habermas 1979:65; McCarthy 1978:290; McCarthy 1979:xviii).

* daar 'n drievoudige relasie bestaan tussen die uitdrukking en:

* die 'eksterne wêreld' as 'n totaliteit van die bestaande stand van sake (die wêreld van objekte en gebeure waaroor ware of valse opmerkings gemaak kan word);

** die 'sosiale wêreld' as die totaliteit van alle normatief gereguleerde interpersoonlike verhoudings wat legitiem is in 'n gegewe samelewing (instellings, tradisies en kulturele waardes en norme, rolle en reëls); en

** 'n spesifieke 'innerlike wêreld' as die totaliteit van intensionele ervarings (Habermas 1979:67). (Taal word verstaan as die interrelasie van hierdie drie wêrelde.)

\section{SISTEMATIES VERWRONGE KOMMUNIKASIE IN LUKAS 14:1-6}

Hierdie teks is geskik vir die toepassing van Habermas se dialekties-kritiese teorie omdat dit getuienis is van spanning en konflik tussen Jesus en die Fariseërs (vgl Tannehill 1986:185; Ressequie 1982:4, 47; Van Staden 1990:216). Jesus en die Fariseërs voer met mekaar gesprek oor die viering van die sabbatdag. In hierdie 
dialoog is daar (verskuilde) motiewe en belange van die akteurs/sprekers aanduibaar. Dit is ons bedoeling om met behulp van Habermas se dialekties-kritiese teorie die (verkuilde) motiewe en belange wat agter die woorde en gedrag van die akteurs/sprekers verskuil lê, te identifiseer. Op so 'n wyse kan daar vasgestel word of daar in die diskoers sprake is of van sistematies verwronge kommunikasie of van 'n ideale gespreksituasie wat getuig van intersubjektiewe wedersydse verstaan.

In die eksegese van Lukas 14:1-6 word veral aan die volgende drie sake aandag gee:

- Die illokusionêre en proposisionele komponente in die teks word aangetoon;

* Die vraag word beantwoord of daar op grond van bogenoemde analise konsensus of ' $n$ afwyking van die geldigheidsaansprake aanwesig is; met ander woorde: is sistematies verwronge kommunikasie aantoonbaar?

* Daar word ingegaan op die vraag of daar sprake is van 'n ideale gespreksituasie; is 'n simmetrie tussen selfhandhawing en dispuut, bekendmaking en verberging, voorskrywing en aanpassing aanduibaar?

Die beantwoording van hierdie vrae word gelei deur bepaalde frases in Lukas 14:1-6 te beklemtoon.

\subsection{Lukas 14:1-6}

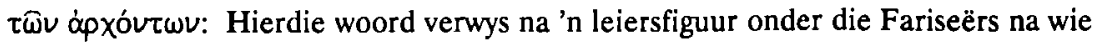
se huis Jesus op 'n Sabbatdag gegaan het om daar te eet. Wat die gebruik van die woord betref, stel Tannehill (1986:183) dat die 'dinner quests are assumed to be people of social standing, people of a rank similar to the ruler who invited them' (vgl ook Neyrey 1990:385; Van Staden 1990:190-220 in verband met die sisteem van klassifikasie wat in die eerste-eeuse Mediterreense samelewing gegeld het). In vers 1 het ons ' $n$ proposisionele sin wat die saak aandui waaroor die deelnemers kommunikeer. Die saak is die maaltyd op die sabbatdag in die huis van een van die leiers van die Fariseërs (kyk Smith 1987; Moessner 1988; Neyrey 1990).

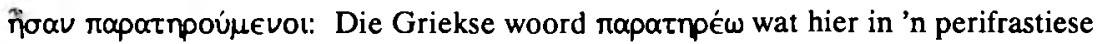
konstruksie gebruik word, is 'n intensionele werkwoord wat die bedoeling van die Fariseërs bekend maak. Sowel Jesus se motief om by die vooraanstaande Fariseër te gaan eet as die motief van die Fariseërs om Jesus fyn dop te hou, is suspisieus (kyk Tannehill 1986:182). In 'n konteks van konflik tussen Jesus en die Fariseërs dui bogenoemde uitdrukking daarop dat die Skrifgeleerdes en die Fariseërs planne beraam om Jesus vas te trek (Tannehill 1986:183; Tiede 1988:261). Hierdie dophou van die Fariseërs is om te sien of Jesus die reinigingsmaatreëls, soos die viering van die sabbatdag, onderhou (Fitzmyer 1982:1041; Van Staden 1990:216). Op grond 
van hierdie vertellerskommentaar kan ons aflei dat, alhoewel die gaste (insluitende Jesus self) van dieselfde sosiale stand is, die Fariseërs hulle self openbaar as die hoogmoediges en selfsugtiges (Plummer 1898:355).

Verwringing is aanwesig weens die afwyking van die geldigheidsaanspraak van betroubaarheid. Die Fariseërs is volgens die vertelling openlik onbetroubaar. Hulle het verskuilde motiewe of belange.

Vers 2 is 'n proposisionele sin wat die situasie van Jesus se optrede beskryf. Die saak wat beskryf word, is die genesing op 'n sabbatdag. Geen illokusionêre komponente met performatiewe werkwoorde wat ' $n$ interpersoonlike verhouding tot stand bring, is aanwesig nie. Die geldigheidsaanspraak word met ander woorde nie met die oog op korrektheid gehandhaaf nie.

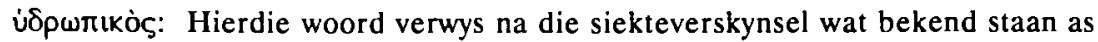
'watersug'. Watersug is die abnormale toename van waterige vloeistof in die weefsels en selle van die liggaam. Tegnies word in die eerste-eeuse Mediterreense samelewing vier soorte watersiekte onderskei na aanleiding van die plek waar dit in die liggaam voorkom: buikwater, borsholte, hartwater en voete en bene (Harrison 1962:872). Volgens Strack \& Billerbeck (1924:203) is daar gedurende die NuweTestamentiese tyd gemeen dat 'watersiekte' deur drie dinge veroorsaak kan word:

* Die sogenaamde gees of demoon van kortasem: Watersiekte veroorsaak dat die persoon kort van asem is. In hom is dus die gees of demoon van kortasem werksaam;

* Sondigheid of immoraliteit: Die destydse opvatting was dat die mens uit gelyke dele water en bloed bestaan. As hy/sy deugsaam is, meng die water en bloed nie. Maar as hy/sy sondig, beweeg die water na die bloed en die gevolg is watersug. Sodanige persoon is onrein omdat die 'grense' verduister of verdof word (vgl Neyrey 1990:282). Die beweging van die bloed na die water toe kan 'n veluitslag veroorsaak. Daarom is 'melaatsheid' dikwels tot hierdie selfde probleem teruggevoer. 'n Kenteken van immoraliteit is dus watersug (Freedman 1938:154; Grundmann 1961:291).

- Straf, vloek of oordeel: Soos ons na aanleiding van die vorige punt gesien het, dui watersug op onreinheid wat weer teruggevoer kan word na 'n waarskynlike goddelike oordeel (kyk Tiede 1988:261). Die siekte kan daarom 'n aanduiding wees van 'n vloek (vgl Num 5:21-22; Plummer 1898:354). Die siekte is in sekere gevalle gesien as 'n straf op die aanbidding van die goue kalf (Strack \& Billerbeck 1924:203).

Verwringing vind derhalwe plaas deurdat die siek man as gevolg van sy 'onreinheid' deur die Fariseërs uit die sosiale sisteem en van sosiale kontak uitgesluit is (vgl Pilch 1990:207). 


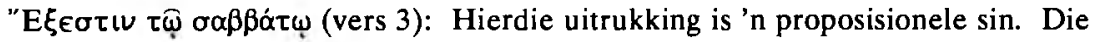
saak van die sabbatdaggenesing is nog aan die orde. Met behulp van 'n retoriese vraag beskryf Jesus sy intensie van medelye ten opsigte van sy medemens. Hierdie intensie is, vanuit die Fariseërs se perspektief gesien, nie betroubaar nie. Weens húlle intensie (vers 1) antwoord hulle Jesus nie (Plummer 1898:354). Ons verskil daarom van Fitzmyer (1985:1041, 1042) wat stel dat die Fariseërs se stilswye 'n instemming met Jesus se vraag betuig. Met hulle stilswye verbind hulle hulle nie in 'n interpersoonlike verhouding met Jesus nie. Jesus daag die Fariseërs se streng onderhouding van die sabbatdag uit. In hierdie 'type-scene' (Tannehill 1986:171), waar die Fariseërs Jesus wil vastrek omdat $\mathrm{Hy}$ nie die sabbatdag onderhou nie, het Jesus hulle poging as vrugteloos afgemaak (Tannehill 1986:183).

Is hier sprake van gedwonge konsensus (stilswye is instemming van die Fariseërs - Fitzmyer 1985:1041, 1042) of kan ons uit die Fariseërs se stilswye aflei dat hulle Jesus nie verstaan het nie? Die kasuïsties bepaalde oorwegings van die wetgeleerdes laat egter geen antwoord toe nie (Grundmann 1961:291). In vers 3 is verwronge kommunikasie dus aanwesig en nie konsensus nie. Jesus gee die sabbatdagsimbool nuwe betekenis - 'n betekenis wat afwyk van die Fariseërs se taalsisteem. ' $n$ Ideale gespreksituasie of wedersydse verstaan ontbreek derhalwe.

Deur middel van die genesing van die man met water, stel Jesus die verwronge kommunikasie reg. Die man word weer in die sosiale sisteem opgeneem en geakkommodeer. Sy pyn (uitsluiting as gevolg van onreinheid) word weggeneem.

Jesus ruil die rolle hier om en blyk die meerdere te wees. Hulle word die mond

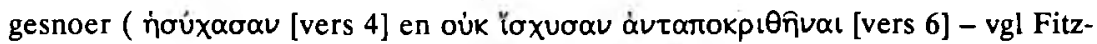
myer 1985:1039, 1040). Deur te swyg het die Fariseërs hulle wese verberg.

Die retoriese vraag in vers 5 en 6 is ook 'n proposisionele sin. Jesus en die Fariseërs is in gesprek oor die saak van die sabbatdaggenesing. Die Fariseërs se selfsugtige belange verhinder hulle om die ware feite te openbaar (Grundmann 1961:355). Hulle intensie is verborge en onbetroubaar, terwyl 'n legitieme interpersoonlike verhouding afwesig is. Verwronge kommunikasie is aanwesig omdat daar nie konsensus bestaan oor die geldigheidsaansprake nie. Vers 5 en 6 verteenwoordig nie ' $n$ jdeale gespreksituasie nie.

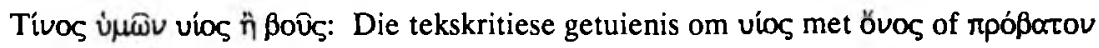
in vers 5 te vervang, is baie verdeeld. Volgens Plummer (1898:355) behoort ons nie die tekskritiese voorstel te aanvaar nie. Grundmann (1961:292) en Tiede (1988: 262) bevestig Plummer se standpunt. Volgens Tiede (1988:262) sluit Jesus by die Qumran-geskrifte aan. Die verwysing na 'seun' en 'os' in dieselfde asem beteken dat selfs die mees rigiede interpreteerders saam behoort te stem dat 'n persoon in nood gehelp moet word. 
In die vraag en antwoord (Luk 14:5, 6) handhaaf Jesus Homself en betwis Hy die intensie van die Fariseërs met betrekking tot die onderhouding van die sabbatdag (Tiede 1988:263). In hierdie perikoop is 'n assimmetrie aanwesig omdat Jesus Homself handhaaf en bekend maak, terwyl die Fariseërs hulleself verberg. Hulle betwis nie Jesus se vraag in vers 5 nie (kyk Grundmann 1961:292; Plummer 1898: 356; Tiede 1988:262).

\subsection{Gevolgtrekkings}

* Die illokusionêre komponent kom nie in die betrokke taalhandeling voor nie. Daar bestaan geen interpersoonlike verhouding nie. Die proposisionele komponent oorheers die taalhandeling en reflekteer teenoorstaande belange met betrekking tot die sabbatdaggenesing van Jesus en die Fariseërs onderskeidelik. Konflik is aan die orde van die dag en opponerende perspektiewe is aanwesig. Dit kan beskryf word as die Fariseërs se selfverhogingsmotief en Jesus se nederigheidsmotief (kyk Fitzmyer 1985:1043; Ressequie 1982:44, 47; Moessner 1988:175; Van Staden 1990:173, 222). Verskuilde intensies en verborge onbetroubaarheid kom ook voor. In hierdie taalhandeling is daar geen wedersydse verstaan aanwesig nie.

* In Lukas 14:1-6 vind sistematies verwronge kommunikasie met ander woorde wel plaas. Die man word op grond van die Fariseërs se toepassing van die reinheidsmaatreëls uitgesluit van die beskutte samelewing. Maar Jesus herstel die verwringing deur die man te genees. Daar is geen konsensus oor die geldigheidsaansprake nie. Dit is nie ' $n$ ideale gespreksituasie nie (vgl ook Pilch 1990:181-209).

* Die kommunikasiegebeure voldoen nie aan die strukturele voorwaardes vir 'n ideale gespreksituasie nie. Die intersubjektiwiteit word geskaad deur wedersydse misverstand. Dialoog-bepalende universele elemente (performatiewe en aanwysende elemente) is afwesig. Wat die deelnemers betref, is daar nie ' $n$ suiwer simmetrie tussen selfhandhawing en dispuut, bekendmaking en verberging, voorskrywing en aanpassing nie. Die volgende vrae bly vervolgens nog onbeantwoord: Watter tipe belange is hier ter sprake? Lê die verskuilde belange in sosiale strukture en instellings?

\section{JÜRGEN HABERMAS IN DIE LIG VAN DIE SOSIAAL-WETENSKAPLIKE BENADERING}

Die toepassing van Habermas se kritiese teorie op 'n teks (Lukas 14:1-6) kan sinvol getoets en gekontroleer word aan die hand van bestaande eksegetiese modelle in die hedendaagse sosiaal-wetenskaplike benadering. Met behulp van veral die ken- 
nissosiologie kan die sosiale sisteem waarin die interaksie tussen mense plaasvind, aangetoon word. Kennissosiologie gee vir ons insig in sake soos sosiale instellings, rolle, hersosialisering, legitimasie en simboliese universum van die eerste-eeuse Mediterreense wêreld waarbinne ons teks aanvanklik bedoel was om te kommunikeer (kyk o a Malina 1981; Neyrey 1990; Van Staden 1990:59).

Volgens Elliott (1981, 1989; kyk ook Van Staden 1990:57) is dit die bedoeling van die sosiaal-wetenskaplike kritiek om bestaande metodes van Bybelse interpretasie, soos die historiese kritiek, te komplementeer en te verbeter deur meer ernstig aandag te gee aan sowel die sosiale dimensie van Bybelse tekste as die sosiologiese dimensie van eksegetiese werk as sodanig. Hy beklemtoon die belangrikheid van die teks omdat dit self die enigste primêre getuienis is van die teks se eie spesifieke situasie. Literêre analise, soos byvoorbeeld die vertellersperspektiefanalise, ondersoek die teks met die oog op veral die literêre strategie van die outeur/ verteller. Sodoende kan 'n situasie afgelei word waarin die spesifieke strategie betekenis het (Van Staden 1990:57).

Die konsep 'situasie' sluit volgens Elliott (1989:8; in Van Staden 1990:57, 58) verskeie vlakke en fases in. Die makrososiale vlak ondersoek die makrososiale konteks van die teks. Dit is die totale sosiale sisteem waarin die teks ontstaan en gekommunikeer het. Die mikrososiale vlak van 'n teks ondersoek die meer spesifieke sosiale toestande en kenmerke van die teks se spesifieke sender(s) en ontvanger(s). 'n Beskrywing van die situasie van 'n teks word hoofsaaklik deur die gebruikmaking van sosiaal-wetenskaplike metodes gesoek. Soos in alle geesteswetenskappe word daar in die sosiologie verskillende teoretiese benaderings onderskei. Van Staden (1990:10) stel dit soos volg: 'Some are interested in macrosociological matters relating to groups, institutions and societies (i.e, functionalism, conflict theory), while others concern themselves with micro-sociological issues relating to individuals (symbolic interactionism, role theory' (vir 'n toepassing van bogenoemde benaderings, kyk Malina 1988:3-30; Pilch 1988:31-62; Neyrey 1988:6392).

Die sosiaal-wetenskaplike perspektief van waaruit ons in kritiese gesprek met Habermas wil gaan, hoort tuis op die makro-sosiologiese vlak (Neyrey 1990; Elliott 1991) sowel as op die mikro-sosiologiese vlak (Neyrey 1990; Van Staden 1990).

\subsection{Habermas en die makro-sosiale vlak (konflikteorie)}

Van Staden (1990:121-129) gee 'n verduidelikende bespreking van konflikteorie (kyk ook Malina 1988:3-30; Malina \& Neyrey 1990:97-122). Enkele aspekte hiervan is geskik vir ons ondersoek. Volgens konflikteorie genereer die samelewing konflik as gevolg van onder andere die ongelyke verspreiding van lewensmiddele. Ongelyk- 
heid ('inequality') is derhalwe 'n bron van konflik. Konflik-teorie verklaar die orde in die samelewing as hoofsaaklik die resultaat van mag wat sekere mense het in demanding compliance from others' (Cohen, in Van Staden 1990:125).

Malina (1988:9; kyk ook Van Staden:1990:125) definieer konflikteorie as 'n perspektief waarvolgens menslike sosiale verhoudings in 'n samelewing ontwikkel, behou en verander word omdat mense gemotiveer word om op te tree in terme van hulle eie belange wat gewoonlik indruis teen die belange van ander. Konflikteorie wil daarom reflekteer oor die oorsake van sosiale verandering. Die basiese vooronderstelling van konflikteorie is die bestaan van een of ander soort van grief van sommige mense wat onderdruk word of wat glo dat hulle onderdruk is.

Van Staden (1990:129) som die konflikteoriemodel soos volg op:

* belange is die basiese elemente van die sosiale lewe;

* sosiale lewe sluit oorsaak en konflik in;

- sosiale lewe is noodwendig verdelend;

* sosiale lewe genereer opposisie, uitsluiting en vyandigheid;

* sosiale lewe genereer gestruktureerde konflik;

* sosiale lewe genereer groepsbelange;

* sosiale differensiasie sluit mag in;

* sosiale sisteme is verkeerdelik geïntegreer en vol 'kontradiksies'; en

- sosiale sisteme blyk te verander.

Al hierdie aspekte word duidelik in 'n resente sosiaal-wetenskaplike studie van Elliott (1991:88-120) met betrekking tot Lukas-Handelinge aangetoon. Hy gaan in hierdie studie in op die tempel en die Christelike huishouding as opponerende sosiale instellings in Lukas-Handelinge. Die aktiwiteite wat met die tempel geassosieer word, is volgens Elliott (1991:97) die volgende: offers, gebed, lofprysing, openbaring, hoop op verlossing, tiendes en wetsonderhouding. Verdere aktiwiteite wat met die tempel geassosieer word, is priesterlik-politieke mag, ekonomiese ongelykheid, Skrifarrogansie en uitbuiting van die armes, konflik van Jesus en sy volgelinge met die tempelowerhede, die Jesus-beweging se kritiek op die tempelinstelling, moordkomplotte en onregverdige veroordelings van die kant van die tempelowerhede (Elliott 1991:97, 98, 101, 102, 108). Die tempel is dus die sentrum van die Joodse politieke, ekonomiese, sosiale en kulturele (godsdienstige) magsbelange. Die tempel word met ander woorde geassosieer met onderdrukking en eksploitasie van sekere mense in die samelewing, soos veral die 'peasant'-gemeenskappe.

In teenstelling met die tempel is die Christelike huishoudings op ekonomiese en sosiale gebied selfonderhoudende gemeenskappe wat georganiseer was op die basis van familiebetrekkinge en huishoudelike bestuur. Polities het hulle 'n relatiewe 
onbelangrike rol in terme van die destydse magstrukture gespeel. 'n Mens kan daarom die Christelike huishoudings (ten minste soos dit in Handelinge voorgestel word) in 'n sekere sin as 'apolities' beskryf. Dit het egter nie beteken dat dit inderdaad elite-families was wat die belangrike politieke magsposisies (wat die tempelgesagstruktuur betref) beklee het nie. Die Christelike huishoudings moet volgens Lukas-Handelinge hiervan onderskei word. Die huishoudelike organisasie is bepaal deur familiale strukture en die tradisionele gebruike en kodes van die familielewe en familieverhoudinge (Elliot 1991:107).

Die kontras tussen tempel en huishouding is dus baie duidelik (Elliott 1991:107):

* politieke instelling teenoor familiale instelling;

* sentralisasie van mag teenoor verspreiding van magtelose huishoudings;

* ekonomiese uitbuiting teenoor resiproke onderlinge versorging;

* eksklusiwiteit vanweë status en klas op grond van reinheid teenoor inklusiwiteit as gevolg van (fiktiewe) familiebande;

* uitsluiting en vervreemding gebaseer op reinheidsgebruike teenoor insluiting gebaseer op genade en geloof.

Die toepassing van die kritiese teorie van Habermas op Lukas 14:1-6 word bevestig deurdat verskuilde belange inderdaad aangetoon kan word. Om Habermas se teorie toe te pas op 'n Bybelteks kan egter lei tot 'n anakronistiese interpretasie. Dit is omdat die dialekties-kritiese teorie vanuit die perspektief van die neo-Marxisme (gerig op twintigste-eeuse ekonomiese en politieke instellings en Westerse kulturele waardes) ' $n$ teks (uit die eerste-eeuse familiale en politieke instellings en Mediterreense kulturele waardes) lees sonder om noodwendig die afstand hermeneuties te oorbrug. Die sosiaal-wetenskaplike studies van die Nuwe-Testament toon aan dat dit nie primerr sosio-ekonomiese en politieke magsbelange is wat tot manipulasie, eksploitasie en verwronge kommunikasie gelei het nie, maar veral familiale belange.

Die gebruikmaking van sosiologiese modelle wat vir die eerste-eeuse Mediterreense situasie geskik is, kan help om die hermeneutiese dwaling van anakronisme te vermy. Volgens Van Staden $(1990: 160,161)$ is die voordeel van die 'cross-cultural model' en die 'comparative model' (Elliott 1991:110) dat dit juis bedag is op anakronisme. Deur hierdie modelle te implimenteer vermy die sosiaal-wetenskaplike eksegeet grootliks hierdie dwaling (Neyrey 1990:xi). Elliott (1991:110) stel dat die betekenis van spesifieke instellings en groepe in Lukas-Handelinge en hulle funksie in die narratief die beste vasgestel kan word deur hulle te ondersoek in relasie tot die sosiale relasies wat tipies is van die samelewing waarin en vir wie Lukas geskryf het. Onderliggend aan die ekonomiese en sosiale wyses van interaksie en konflik van die wêreld waarvan Lukas-Handelinge deel is, is breër oppo- 
nerende patrone van relasies wat gebaseer is op antieke sisteme van of resiproke verantwoordelikheid (soos die $\mathrm{m} \mathrm{b}$ t byvoorbeeld 'patron-client'-verhoudinge) of algemene interaksie. Die wederkerige (direkte, persoon-tot-persoon gee en neem) vorme van interaksie is kenmerkend van die huishouding en plaaslike plattelandse lewe in die eerste-eeuse Palestina. Die gesentraliseerde akkumulasie van landbousurplus en herverdeling is tipies van die algemene tempel-gebaseerde ekonomie. Verdeling geskied op grond van die behoeftes van hulle wat die mag (polities, ekonomies, sosiaal en ideologies beheer) besit. Dit is dus wel so dat die ekonomiese en sosiale verhoudinge in die eerste-eeuse Palestina ongebalanseerd was en dat verskillende 'klasse' voorgekom het.

Op grond van die primêre navorsing deur die Noorweegse Nuwe-Testamentikus, Halvor Moxnes, stel Elliott (1991:110) dat 'these contrasting modes of social exhange played a key role in shaping social dimensions of the conflict between the Jesus movement and the Tempel establishment as described in Luke-Acts.'

Vanuit hierdie uiteensetting kan ons konkludeer dat die sosiaal-wetenskaplike benadering Habermas se hipotese bevestig en tegelykertyd korrigeer. Die Fariseërs (wat in ' $n$ bepaalde opsig die eksklusiwistiese waardes van die tempelowerhede gedeel het) het vanuit die tempel as sosiale instelling met die priesterlik-aristokratiese families se ekonomiese, politieke, sosiale en godsdienstige magsbelange die 'peasant'-gemeenskappe ekonomies uitgebuit en sosiaal verag. Die Jesus-beweging word deur Lukas-Handelinge voorgestel in terme van die huishouding as opponerende sosiale instelling. Die tempelowerhede veroorsaak die verwronge kommunikasie en belemmer die ideale gespreksituasie.

\subsection{Habermas en die mikro-sosiale vlak (rolteorie)}

'n Sosiaal-wetenskaplike eksegetiese benadering kan die vorm van verskillende teoretiese perspektiewe aanneem, naamlik die struktureel-funksionalistiese teorie, konflikteorie en interaksieteorie (kyk Van Staden 1990:114-146). Die interaksieteorie het twee variante, naamlik simboliese interaksie (Neyrey 1988:63-92) en rolteorie (Van Staden 1990:133). Vir die doel van ons ondersoek gee ons aandag aan die rolteorie. Die terme 'rol' en 'posisie' gaan so vanselfsprekend met mekaar saam dat hulle slegs vir analitiese doeleindes geskei word. 'Posisie' verwys na die strukturele aspek van die interaksiesituasie, naamlik wie 'n persoon is. Die terme 'posisie' en 'status' word dikwels as wisselterme gebruik. 'n Onderskeid is egter tog nodig, omdat 'status' verwys na die prestige wat 'n posisie het in verhouding tot ander posisies, en dus 'n vertikale rangordening van posisies impliseer. 'Rol' verwys na die handeling wat van die persoon in 'n bepaalde posisie verwag kan word. Dit kan beskryf word as die rolverwagtings wat vanuit die aard van die samestelling van die samelewing aan die persoon gestel word (Van Aarde 1990). 
Van Staden (1990:146) ondersoek 'rol' en 'status' in die Lukasevangelie met behulp van die rolteorie. Dit veronderstel volgens hom 'n perspektief op die samelewing vanuit ' $n$ konflikteorie. Dit beteken dat die resultate wat deur ' $n$ analise op die mikro-sosiale vlak van interaksiesituasies verkry word, onderwerp sal word aan ' $n$ interpretasie op die makro-sosiale vlak, gekonstitueer deur die narratiewe wêreld as geheel. Die twee belangrikste opponerende ideologieë wat in die Lukasevangelie as narratief aangetref word, is die "exaltation-oriented point of view of the Pharisees, as opposed to a humiliation-oriented point of view of Jesus...' (Ressequie 1982:45; Van Staden 1990:173). Die doel van Van Staden se ondersoek was om die hipotese te toets dat Lukas die algemene verwagtinge wat aan 'n hoë status gekoppel is, herdefinieer. Sy resultaat was dat die bereidheid om te dien - 'n rol wat met 'n lae status geassosieer word - volgens Jesus se ideologie deel moet word van die verwagtinge van almal wat 'n hoë status beklee (Van Staden 1990:171).

Vanweë die agoniese (wedywerende) aard van die Mediterreense samelewing word die orde in die samelewing verklaar as die resultaat van die mag wat sekere mense oor ander het (Neyrey 1990:xvii). Dit kom neer op magsuitoefening met betrekking tot die skaars middele waaroor mense voortdurend wedywer. Konflik kom dus voor in die gewone gang van sosiale interaksie wanneer die legitimiteit van die mag van bestaande maghebbers bevraagteken word (Van Staden 1990:189). So 'n perspektief gaan van die veronderstelling uit dat die Fariseërs en die Skrifgeleerdes die gesag ('legitimate power') het in die mate dat hulle interpretasie van God se wil (die simboliese universum) aanvaar en erken word deur en gemanifesteer word in die samelewing. Die simboliese universum (wat mitologiese en kosmologiese aspekte insluit) is die sisteem wat lyne/grense, definisies en klassifikasies in 'n gegewe kultuur beinvloed (Neyrey 1990:274). Die simboliese universum van die Farisese ideologie is veral gekonstitueer met die kernwaarde van heiligheid, heelheid en reinheid (wat na eksklusiwisme gelei het). Ideologies het dit uitdrukking gevind in die Fariseërs se onderrig aangaande hulle definisies van hoe die sosiale orde daar behoort uit te sien (Neyrey 1990:378; Van Staden 1990:189).

Volgens Lukas-Handelinge lyk dit of die Fariseërs deel is van die hoë status groep. Jesus ervaar die Fariseërs se definisie as neerdrukkend van aard. Hy word daardeur gegrief en dit lei daartoe dat Hy hulle konsep van die sosiale orde en waardes wat dit beïnvloed, verwerp. Jesus stel sy eie interpretasie van die simboliese universum voorop. Hieruit lei Hy die kernwaarde van medelye (dit is, inklusief) af as die essensie van sosiale interaksie (Neyrey 1990:303; Van Staden 1990:189).

Van Staden bevestig oortuigend sy hipotese van Lukas se herdefinisie van die regte en pligte van die maghebbers. Medelye is ook die verpligting van diegene met hoë status om soos 'n slaaf te dien. Die bestaan van 'n patroon van omkering 
('reversal') van rol of status bevestig ook die resultaat van die narratiewe analise van Ressequie dat twee opponerende ideologiese perspektiewe in die Lukasevangelie gereflekteer word. Dit ondersteun ook die siening van Neyrey dat medelye die verantwoordelikheid van die individu is wat 'n relatiewe hoë status in die samelewing het (Neyrey 1990:294-301; Van Staden 1990:190).

Habermas kan dus korrektief aangevul word deur middel van die gebruikmaking van die sosiaal-wetenskaplike rol-teorie in die eksegese van Lukas 14:1-6. Jesus wil die sosiale orde verander (in lyn met Habermas se teorie) deur ' $n$ gesindheidsverandering te weeg te bring by die hoê status persone, maar nie deur magsoorname nie. Verwringing het wel plaasgevind as gevolg van die verskuilde ekonomiese, politieke en godsdienstige magsbelange van die Fariseërs (Habermas bevestig). Die verwringing is gegrond in die onderskeidelike verstaan en beklemtoning van verskillende waardes (God se heiligheid-as-skeiding teenoor God se genade-asinklusiwiteit of onpartydigheid - kyk Neyrey 1990:303).

Habermas se dialekties-kritiese teorie is dus met groter sukses op Lukas 14:1-6 toegepas deurdat dit aangevul is met insigte vanuit die sosiaal-wetenskaplike kritiek, soos aangewend in die Nuwe-Testamentiese wetenskap deur onder andere $\mathrm{J} \mathrm{H} \mathrm{El}$ liott (1981, 1989, 1991), J Neyrey (1990) en P van Staden (1990).

\section{EVALUERING}

In afdeling 2 is die epistemologie grondliggend aan die dialekties-kritiese teorie aangedui as ' $n$ proses van selfrefleksie waarin individue bewus word van hulle krag teen feitelike of tradisionele magte in die samelewing. Sodra individue insig verkry in die veranderende aard van sosiale wette of gestolde tradisies wat hulle optredes beheer, kan hulle op grond van hierdie insig hulle omstandighede self verander en kan emansipasie gevolglik plaasvind (Habermas se sogenoemde pragmatiese belang).

Sistematiese verwronge kommunikasie is in afdeling 3 aangedui as die foutiewe organisering van die gesprek self met onverstaanbaarheid as resultaat. In afdeling 4 is Habermas se model vir linguistiese kommunikasie gedefinieer. Universele pragmatiek of kommunikatiewe kompetensie identifiseer en rekonstrueer universele voorwaardes van moontlike verstaan. Die doel om tot verstaan te kom is om 'n ooreenkoms te bereik. Ooreenkoms is gebaseer op erkenning van ooreenstemmende geldigheidsaansprake van verstaanbaarheid, waarheid, betroubaarheid en konkreetheid.

Sistematies verwronge kommunikasie in Lukas 14:1-6 is in afdeling 5 aangetoon. Verwringing is gegrond in die teenstellende verstaan en beklemtoning van verskillende waardes (God se heiligheid-as-skeiding teenoor God se genade-as- 
inklusiwiteit of onpartydigheid). In afdeling 6 is Habermas se kritiese teorie sinvol getoets en gekontroleer aan die hand van sekere resultate van bestaande modelle in die hedendaagse sosiaal-wetenskaplike benadering tot die eksegese van die Nuwe Testament. Die toepassing van die kritiese teorie van Habermas op Lukas 14:1-6 word bevestig deurdat verskuilde belange inderdaad aangetoon kan word. Ten spyte daarvan dat sy kritiese teorie gerig is op die industriële samelewing, is daar betoog dat die teorie ook relevant vir die bestudering van 'n voor-industriële samelewingsteks soos die Bybel kan wees, sonder om aan anakronisme skuldig te wees.

Ten slotte is drie opmerkings hier van pas: Eerstens, Habermas se analise kan ons sensitief maak vir die moontlikheid van sodanige verwringing in alle menslike handelinge en veral taalhandelinge. Tweedens, sy teorie van kommunikatiewe kompetensie is 'n herinnering dat enige poging om 'n tradisie krities te rekonstrueer, 'n weg sal moet vind tot die intersubjektiewe verwesenliking ('validating') van sentrale beginsels. Indien dit nie gebeur nie, sal daar moeilik op algemene geldigheid aanspraak gemaak kan word. Die afwesigheid van sodanige intersubjektiewe geldigheid/waardering is kenmerkend van baie bevrydingsteologieë. Derdens, is daar die vraag na die teologiese gesag van die kritiese beginsels wat gebruik word om die Christelike leer te rekonstrueer:

For Christian theology, the definitive criterion of truth lies in the revelation of Jesus Christ. This revelation is not just a future ideal, but has taken historical expression. Thus, any attempt to formulate a critical theory for reconstructing Christian tradition must find some way of grounding this theory in the historical revelation of Jesus Christ.

(Maddox 1985:529)

\section{Literatuurverwysings}

Botha, J E 1991. Jesus and the Samaritan woman: A speech-act reading of John 4:142. Leiden: Brill. (Supplements to Novum Testamentum.)

Elliott, J H 1981. A home for the homeless: A sociological exegesis of 1 Peter, its situation and strategy. London: SCM.

- 1989. Social-scientific study of the Bible and the biblical world. Unpublished study material providing an introduction to the subject. University of San Francisco.

- 1991. Temple versus household in Luke-Acts: A contrast in social institutions. HTS 47/1, 88-120. 
Fitzmyer, J A 1985. The Gospel according to Luke X-XXIV: Introduction, translation and notes. New York: Doubleday.

Freedman, H (ed) 1938. Shabbat in two volumes. London: Soncino Press.

Gorski, P S 1990. Scientism, interpretation and criticism. Joumal of Religion and Science 25/3, 279-303.

Grundmann, W 1961. Das Evangelium nach Lukas. Berlin: Evangelische Verlagsanstalt. (Theologischer Handkommentar zum Neuen Testament.)

Habermas, J 1977. Analytical theory of science and dialectics, in Adorno, T W, The positivist dispute in German sociology, 131-144. London: Heinemann.

- 1979. Communication and the evolution of society. Tr by T MaCarthy. Boston: Beacon Press.

- [1970] 1981a. On systematically distorted communication, in Klemm 1981:209219.

- [1970] 1981b. Towards a theory of communicative competence, in Klemm 1981:221-233.

- 1982. Theorie des kommunikativen Handelns: Handlungrationaliät und gesellschaftliche Rationalisierung, Band 1. Zwei Auflage. Frankfurt a M: Suhrkampf.

- 1983. Moralbewusstsein und kommunikatives Handeln. Frankfurt.

- 1985. Zur Logik der Sozialwissenschaften. Frankfurt.

— 1986. Der philosophische Diskurs der Moderne: Zwölf Vorlesungen. Frankfurt a M: Suhrkampf.

Harrison, R K 1962. s v 'Dropsy'. IDB.

Klemm, D E 1981. Hermeneutical inquiry, Vol 2: The interpretation of existence. Atlanta: Scholars Press. (AAR Studies in Religeon 44.)

Maddox, R L 1985. Contemporary hermeneutic philosophy and theological studies. Religious Studies 21, 517.529.

Malina, B J 1981. The New Testament world: Insights from cultural anthropology. Atlanta: John Knox.

- 1988. A conflict approach to Mark 7. Fonum 4/3, 3-30.

McCarthy, T A 1978. The critical theory of Jürgen Habermas. Cambridge: MIT Press.

- 1979. Translators introduction, in Habermas 1979:vii-xxiv.

McCann, D P 1981. Habermas and the theologians. Religious Studies Review 7/1, 14-21.

Moessner, D P 1988. Lord of the banquet: The literary and theological significance of the Lukan travel narrative. Minneapolis: Fortress.

Neyrey, J H 1988. A symbolic approach to Mark 7. Forum 4/3, 63-91. 
Neyrey, J H (ed) 1990. The world of Luke-Acts: A handbook of social science models for biblical interpretation. Peabody: Hendrickson Publishers.

Pilch, J J 1988. A structural functional analysis of Mark 7. Forum 4/3, 31-62.

Plummer, A 1898. A critical and exegetical commentary on the Gospel according to Luke. Edinburgh: T \& T Clark. (The International Critical Commentary.)

Ressequie, J L 1982. Point of view in the central section of Luke (9:51-19:44). Journal of the Evangelical Theological Society 25/1, 41-47.

Romm, N 1987. Habermas se wetenskapsteorie, in Snyman \& Du Plessis 1987:179197.

Smith, D E 1987. Table fellowship as a literary motif in the Gospel of Luke. JBL $106,613-638$.

Snyman, J J 1987. Die wetenskapsopvatting van die Frunkfurtse skool, in Snyman \& Du Plessis 1987:166-177.

Snyman, J J \& Du Plessis, P G W 1987. Die wetenskapsbeelde in die geesteswetenskappe. Pretoria: RGN.

Strack, H L \& Billerbeck, P 1924. Kommentar zum Neuen Testament aus Talmud und Midrasch: Das Evangelium nach Markus, Lukas und Johannes und die Apostelgeschichte. München: Beck.

Tannehill, R C 1986. The narrative unity of Luke-Acts: A literary interpretation, Vol 1. The Gospel according to Luke. Philadelphia: Fortress.

Tiede, D L 1988. Luke. Minneapolis: Augsburg. (Augsburg commentary on the New Testament.)

Van Aarde, A G 1990. Die sosiaal-wetenskaplike eksegese van die Nuwe Testament. Ongepubliseerde M Div-lesings, Universiteit van Pretoria.

Van Staden, P 1988. A sociological reading of Luke 12:35-48. Neotestamentica 22/2, 337-353.

Van Staden, P 1990. Compassion - The essence of life: A social- scientific study of the religious symbolic universe reflected in the ideology/theology of Luke. Unpublished DD-thesis, University of Pretoria. 